\title{
Precocious endothelial dysfunction in patients with congenital generalized lipodystrophy (Berardinelli-Seip syndrome) evaluated by two different methods
}

\author{
Virgínia Oliveira Fernandes, Ana Paula Dias Rangel Montenegro, Clarisse Mourão Melo Ponte, \\ Lia Beatriz de Azevedo Souza Karbage, Manuela Montenegro Dias de Carvalho, Daniel Duarte Gadelha, \\ Synara Cavalcante Lopes, Marivaldo Loyola Aragão, Ana Paula Abreu Martins Sales, Cristiane Bezerra Rocha Liberato, \\ Ana Gardênia Liberato Ponte Farias, Catarina Brasil D’Alva, Francisco Herlânio Costa Carvalho, \\ Izabella Tamira Galdino Farias Vasconcelos, Carla Antoniana Ferreira de Almeida Vieira, \\ Ana Paula Germano Lopes Cavalcante, Mariella Zaiden Rezende Reis, Renan Magalhães Montenegro Junior ${ }^{*}$
}

From 20th Brazilian Diabetes Society Congress

Porto Alegre, Brazil. 11-18 November 2015

\section{Background}

Berardinelli-Seip syndrome (BS) is a rare disease characterized by severe insulin resistance and absence of subcutaneous fat since birth or early childhood. This condition Results in lipids's ectopic deposit (muscle, liver and arterial walls), which explains its clinical complications as diabetes, hepatic injury, hyperlipidemia and premature atherosclerosis.

\section{Objective}

To evaluate endothelial function with the flow-mediated dilatation of the brachial artery (FMD) and peripheral arterial tonometry (ENDOPAT) in patients with BS.

\section{Matrials and methods}

A cross-sectional study with 11 patients with BS and 14 healthy individuals. They performed clinical evaluation, laboratory exams and FMD evaluation. The BS group also performed EndoPAT evaluation. The data were analyzed in STATA 11.2.

\section{Results}

There was no difference in age and gender between the groups. After adjusted for sex, age and height, BS group had high blood pressure in $88.89 \%$; hypertriglyceridemia in $69.23 \%$; low HDL-c in $84.62 \%$ and hypercholesterolemia in $25 \%$ of the subjects. Left ventricular hypertrophy was observed in $40 \%$ of the BS group and $50 \%$ of BS patients had diabetes. Comparing BS group with control group were observed, respectively, mean systolic BP (mmHg): $127 \pm 23.63$ vs $102.21 \pm 13.40(\mathrm{p}=0.002)$, diastolic BP (mmHg): $78.11 \pm 16.48$ vs $63.21 \pm 5.23(\mathrm{p}=0.002)$, BMI $\left(\mathrm{kg} / \mathrm{m}^{2}\right): 18.94 \pm 2.50$ vs $19.93 \pm 3.27(\mathrm{p}=0.379)$, the body fat percentage at bioelectrical impedance analysis (\%): $8.56 \pm 3.53$ vs $24.5 \pm 7.67(\mathrm{p}=0.000)$, fasting plasma glucose $(\mathrm{mg} / \mathrm{dL}): 109.14 \pm 78.60$ vs $82.43 \pm 10.87(\mathrm{p}=0.713)$, total cholesterol (mg/dL): $192.46 \pm 151.64$ vs $30.33 \pm 179.83$ $(\mathrm{p}=0.423), \mathrm{HDL}-\mathrm{c}(\mathrm{mg} / \mathrm{dL}): 29.84 \pm 8.73$ vs $42.14 \pm 11.45$ $(\mathrm{p}=0.004), \mathrm{LDL}-\mathrm{c}(\mathrm{mg} / \mathrm{dL}): 80.82 \pm 28.04$ vs. $90.21 \pm 23.29$ $\mathrm{mg} / \mathrm{dL}(\mathrm{p}=0.125)$, triglycerides $(\mathrm{mg} / \mathrm{dL}): 188.08 \pm 186.09$ vs $80.57 \pm 38.39(\mathrm{p}=0.003)$. Endothelial disfunction by FMD was presented in $81.8 \%$ of the BS group vs. $30.77 \%$ in control group $(\mathrm{p}=0.012)$. The prevalence ratio was 2.86 (confidence interval: 1.19-6.86). Endothelial disfunction by EndoPAT was observed in $50 \%$ of the subjects with a natural logarithm reactive hyperemia index (LnRHI index) of $0.49 \pm 0.15$. There was a mild agreement between the diagnosis of endothelial dysfunction assessed by FMD and EndoPAT (kappa: 0.40, p=0.056).

\footnotetext{
* Correspondence: renanmmjr@gmail.com

Faculdade de Medicina da Universidade Federal do Ceará, Fortaleza, Brazil
} 


\section{Conclusion}

The results showed that patients with BS presented endothelial dysfunction, even in early ages. It shows the necessity of early intervention in patients to avoid cardiovascular outcomes.

Published: 11 November 2015

doi:10.1186/1758-5996-7-S1-A111

Cite this article as: Fernandes et al:: Precocious endothelial dysfunction in patients with congenital generalized lipodystrophy (Berardinelli-Seip syndrome) evaluated by two different methods. Diabetology \& Metabolic Syndrome 2015 7(Suppl 1):A111.

Submit your next manuscript to BioMed Central and take full advantage of:

- Convenient online submission

- Thorough peer review

- No space constraints or color figure charges

- Immediate publication on acceptance

- Inclusion in PubMed, CAS, Scopus and Google Scholar

- Research which is freely available for redistribution

Submit your manuscript at www.biomedcentral.com/submit 